\title{
THE EFFECT OF A NITRO-ASPIRINE ON APOPTOSIS OF NEUTROPHIL GRANULOCYTES
}

\author{
VASILEV S*, VUČEVIĆ DRAGANA*, GAŠIĆ SONJA*, MAJSTOROVIĆ IVANA*, VASILIJIĆ S*, \\ ČOLIĆ $\mathrm{M}^{*}$ and ĆUPIĆ $\mathrm{V}$ ** \\ *Military Medical Academy, Institute for Medical Research, Belgrade, \\ **Faculty of Veterinary Medicine, Belgrade \\ (Received 3. April 2007)
}

Apoptosis of neutrophil granulocytes is a critical event in the resolution of inflammation. Neutrophils have a short lifespan which can be modulated by aspirin. In this work we studied the effect of a nitroaspirin (NCX4016) on apoptosis of inflammatory granulocytes. This aspirin analogue has been synthesized to reduce the side effects of aspirin in the gastrointestinal tract. Inflammatory granulocytes have been isolated from polyvinyl sponges implanted under the skin of Albino Oxford $(A O)$ rats. Inflammatory cells that were isolated 20 hours later were about $95 \%$ neutrophil granulocytes. The cells were cultivated $24 \mathrm{~h}$ with different concentrations of NCX4016 ranging from $0.25 \mu \mathrm{M}$ to $500 \mu \mathrm{M}$. After that period, apoptosis of neutrophils was assessed by morphological criteria, as well as by flow cytometry (after staining the cells with propidium iodide). We found that NCX4016 at concentrations from 50 to $500 \mu \mathrm{M}$ induced the apoptosis of rat inflammatory granulocytes in a dose-dependent manner. However, at concentrations from $1 \mu \mathrm{M}$ to $10 \mu \mathrm{M}$ it inhibited apoptosis. In conclusion, our results suggest that anti-inflammatory properties of the NO-aspirin are additionally potentiated by the proapoptotic effect on granulocytes, which could be a novel mechanism of their action.

Key words: nitro-aspirin, neutrophil granulocytes, apoptosis

\section{INTRODUCTION}

Non-Steroidal Anti-Inflammatory Drugs (NSAIDs), including aspirin, can cause bleeding and ulceration of gastrointestinal mucosa (Jezdimirović et al., 1996; Ćupić, 1999; Awatry and Loscalzo, 2000). The fact that donors of nitric oxide (NO) effectively reduce the damage of the gastric mucosa (Elliott et al., 1995) and aid the healing process after such damage, as well as the observation that patients who simultaneously received aspirin and NO donors did not have any side effects related to the gastrointestinal tract, turned the research on NSAIDs in a new direction. As a result of these efforts, new NSAIDs, capable of releasing the biological mediator and gastroprotective agent nitric oxide (NO), have been 
synthesized (Bandarage and Janero, 2001). One among them is NCX4016 (Fig. 1) a nitro derivative of aspirin.

Neutrophils are a part of the immune system involved in the host defence against microorganisms. They are the first leukocytes to migrate to the inflammation site, hours before other cells do so, as well (Witko-Sarsat et al., 2000;

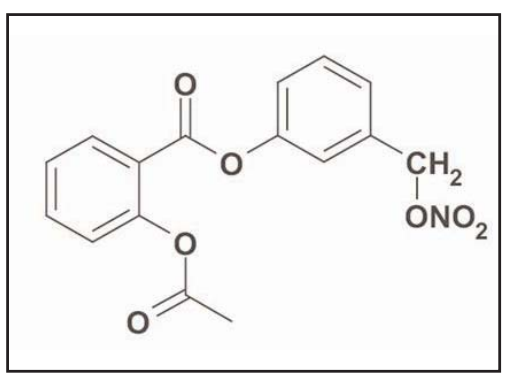

Figure 1. Chemical structure of NCX4016

Girard, 2003). Neutrophil granulocytes have the shortest lifespan among leukocytes (12$48 \mathrm{~h})$. Their lifespan can be modulated by cytokines, pharmacological agents and xenobiotics (Girard, 2003; Maianski et al., 2004).

Apoptosis plays an important role in the development, of tissue homeostasis and in the defence against viral infections and mutations. This process is regulated by complex molecular signalling systems (Kam and Ferch, 2000; Dlamini et al., 2004; Guimaraes and Linden, 2004). Apoptosis of neutrophil granulocytes is important for the resolution of inflammation (Kam and Ferch, 2000), since failure to undergo this form of cell death leads to increased tissue damage and exacerbation of the inflammatory response. Manipulation of the rate of apoptosis in inflammatory neutrophils could be of therapeutic benefit.

The effect of NCX4016 on the apoptosis of inflammatory granulocytes has not been studied before, and thus was the subject of this study.

\section{MATERIALS AND METHODS}

\section{Animals}

Male 10 weeks old Albino Oxford (AO) rats, weighing 200-220 g, bred at the Institute for Medical Research, Military Medical Academy (MMA), Belgrade, were used. The rats were fed standard laboratory chow (Veterinarski zavod Subotica) and tap water ad libitum. All experimental procedures were conducted in adherence to the NIH guidelines for the use of experimental animals, with the approval of the Ethical Committee of MMA.

\section{Neutrophil collection}

Effects of NCX4016 on apoptosis of inflammatory neutrophil granulocytes were studied using a inflammation model by implanting sterile polyvinyl sponges under the skin of rats, as described in our previous work (Vasilev et al., 2006). Briefly, rats were anaesthetized and small incisions were made in the skin on their back, creating subcutaneous pockets. Sterile polyvinyl sponges were implanted subcutaneously and pushed down under the skin. After 20 hours, the rats were killed, the sponges were retrieved aseptically and infiltrated cells from the sponges were collected. Cells were counted in a standard hematocytometer 
chamber. Isolated inflammatory cells were about $95 \%$ neutrophil granulocytes. Viability of neutrophils was about $98 \%$.

\section{Cultivation of neutrophils}

Neutrophil granulocytes were plated in 96 -well plates $\left(5 \times 10^{5}\right.$ cells/well, $200 \mu \mathrm{L})$ along with increasing concentrations $(0.25-500 \mu \mathrm{M})$ of NCX4016 (NicOx, France) and cultivated for $24 \mathrm{~h}$. The control consisted of cells cultivated in complete RPMI 1640 medium. Culture supernatants were collected after $24 \mathrm{~h}$ and used for nitric oxide production measurement. These cells were used for the detection of apoptosis.

\section{Measurement of apoptosis}

For the measurement of apoptosis, two different methods were used. Analysis using morphological criteria (chromatin condensation, nuclear pyknosis or nuclear fragmentation) was performed after fixation and staining of the cells with Türk reagent (Čolić, 2004). Apoptosis was also detected by staining hypodiploid nuclei using propidium iodide (PI) (Migita et al., 1994). After incubation, neutrophils were washed once with phosphate buffered saline (PBS) and resuspended in $0.4 \mathrm{~mL}$ solution with $20 \mu \mathrm{L}$ of $\mathrm{PI}(1 \mu \mathrm{g} / \mathrm{mL})$. Analyses was performed on an EPICS XL-MLC cytofluorometer (Coulter, Germany).

\section{Measurement of NO production}

Production of NO, quantified by the accumulation of nitrite in the $24 \mathrm{~h}$ culture medium, was measured spectrophotometrically using the Griess reaction with sodium nitrite as a standard (Green et al., 1982). Culture supernatants (50 $\mu \mathrm{L})$ were mixed with equal volumes of $1 \%$ sulphanilamide (Sigma Chemicals Co., St Louis, Mo., USA) in $5 \% \mathrm{H}_{3} \mathrm{PO}_{4}$ and $0.1 \% \mathrm{~N}$-1-naphthylethylene diamine dihydrochloride (Sigma Chemicals Co., St Louis, Mo., USA) in distilled water. After 10 minutes the absorbance was measured at room temperature at $570 \mathrm{~nm}$ with $650 \mathrm{~nm}$ reference wavelength.

\section{Statistical analysis}

All data are expressed as mean \pm standard deviation. Each test was performed at least three times. Statistical analysis was performed by Student's ttest, using a PC Program. A p value less than 0.05 was considered significant.

\section{RESULTS}

Effect of NCX4016 on the Apoptosis of Rat Neutrophil Granulocytes

Apoptosis was determined by the morphological method after a 24-hour incubation of neutrophils isolated from sponges impregnated with different concentrations of $\mathrm{NCX} 4016$ at $37^{\circ} \mathrm{C}$. It was found that at concentrations from $1 \mu \mathrm{M}$ to $10 \mu \mathrm{M}$ NCX4016 significantly inhibited spontaneous apoptosis. However, at concentrations from 50 to $500 \mu \mathrm{M}$, NCX4016 induced in the same cells a statistically significant degree of apoptosis in a dose-dependent manner (Fig. 2). Results were confirmed by flow cytometry after staining the cells with PI (Fig. 3). 


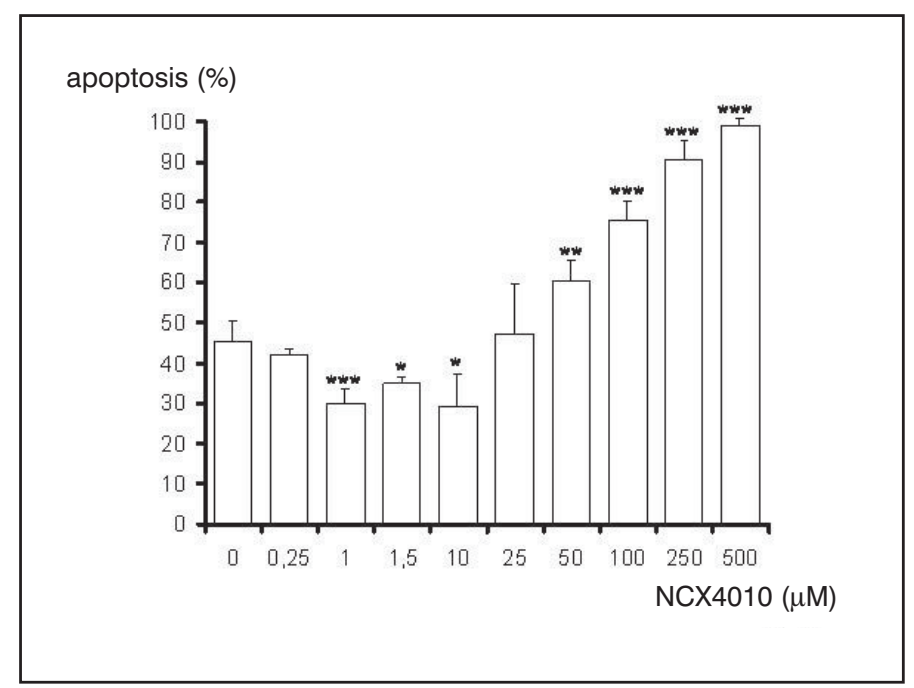

Figure 2. The effect of NCX4016 on apoptosis of cultured neutrophil granulocytes. Apoptosis was measured after staining the cells with Türk reagent and analysis by light microscopy, using morphological criteria as described in Materials and Methods. Values are given as mean \pm SD of triplicates from one representative experiment, out of several ones with similar results. Results of morphological analysis are given on the basis of 500 counted cells in each native preparation $\left({ }^{\star} p<0.05\right.$; ${ }^{* *} p<0.01,{ }^{* * *} p<0.001$ compared to control)

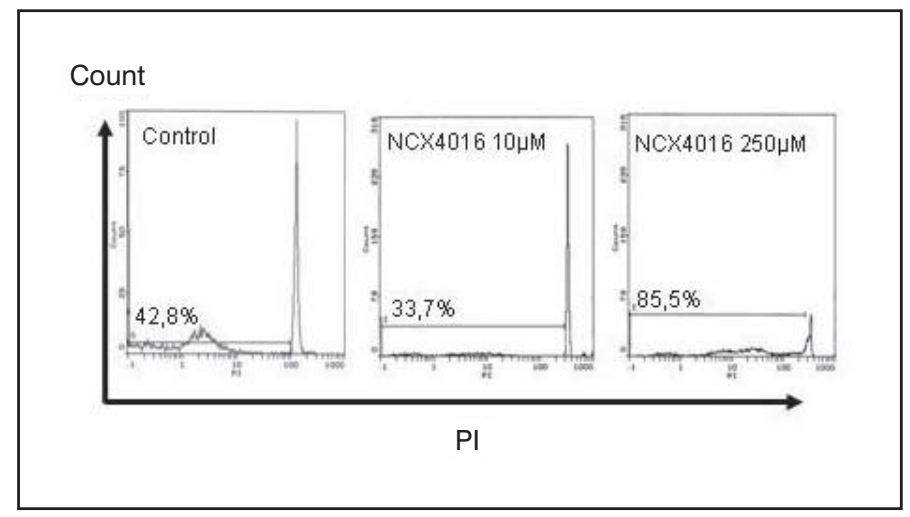

Figure 3. The effect of aspirin on apoptosis of cultured neutrophil granulocytes. Apoptosis was measured after staining the cells with propidium iodide using cytofluorometry as described in Materials and Methods. The number above the horizontal line shows the percentage of hypodiploid nuclei 
Acta Veterinaria (Beograd), Vol. 57. No. 5-6, 403-412, 2007.

Vasilev S et al.: The effect of a nitro-aspirine on

apoptosis of neutrophil granulocytes

\section{Effect of NCX4016 on NO Production}

It is known that NO, depending on the concentration, suppresses or promotes apoptosis. Therefore, in the subsequent experiments, we investigated the effect of different concentrations of NCX4016 on NO production by inflammatory granulocytes. We found that at concentrations lower than $50 \mu \mathrm{M}$, NCX4016 had no effect on the baseline production of NO (as assessed by the quantity of nitrite measured by the Griess reaction) by neutrophil granulocytes cultured for 24 hours. However, in concentrations higher than $50 \mu \mathrm{M}$, NCX4016 caused a statistically significant, dose-dependent decrease of NO production (Fig. 4).

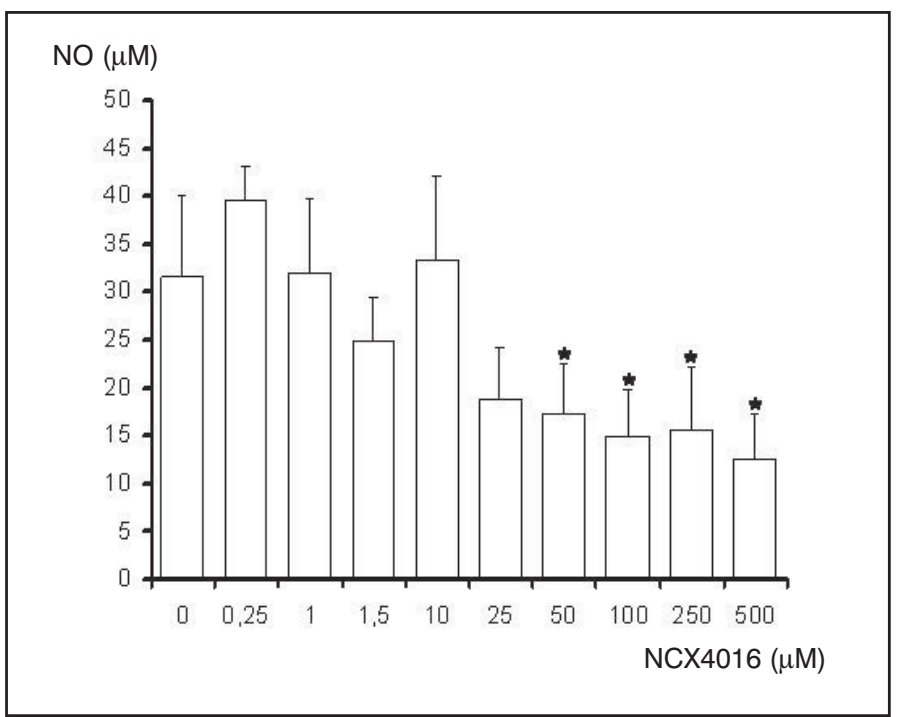

Figure 4. The effect of NCX4016 on the production of nitric oxide by neutrophil granulocytes in $24 \mathrm{~h}$ culture. Production of nitric oxide was measured spectrophotometrically using the Griess method as described in Materials and Methods. Values are given as mean \pm SD of triplicates from one representative experiment, out of several ones with similar results.

${ }^{*} \mathrm{p}<0.05$ compared to control

\section{DISCUSSION}

Aspirin is a widely used effective anti-inflammatory agent. Unfortunately long-term administration of aspirin is accompanied by an increased risk of gastrointestinal ulcerations and bleeding (Vane JR et al., 1998; Awtry and Loscalzo, 2000; Hinz and Brune, 2002; Bolla et al., 2006),

In the last years, nitric oxide (NO)-releasing derivatives of Non Steroidal Antiinflammatory drugs (NSAID), known as nitro-NSAID or NO-NSAID, have received much attention as therapeutic alternatives to their respective original 
NSAID (Del Soldato et al., 1999; Bolla et al., 2006). NO-NSAID cause significantly less gastrointestinal damage in experimental animals than NSAID (Muscara et al., 1998). It has been suggested that NO-NSAID most probably spare the gastrointestinal tract by means of local release of NO, leading to a local increase of blood flow in the gastric mucosa. NO released from NO-NSAID may also contribute to the anti-inflammatory action of these drugs (Mariotto et al., 1995). NO-aspirins, contrary to aspirin, act gastroprotectively, while their antiinflammatory activity is the same, or even greater than that of aspirin (Muscara et al., 1998; Bandarage and Janero, 2001; Burgaud et al., 2002; Di Napoli and Papa, 2003; Bolla et al., 2006). The anti-inflammatory activity of NCX4016 was confirmed in animal models of pain and inflammation. His unique pharmacological profile is obtained through its COX-inhibitory and NO-donating properties (Bolla et al., 2005)

In literature there is no evidence on the influence of NCX4016 on neutrophil apoptosis. In our experiments, we have found that NCX4016 had similar effects on apoptosis of rat inflammatory neutrophil granulocytes like aspirin, but in much lower concentrations. In previous work (Vasilev et al., 2006) we have shown that aspirin after 24 hours of incubation at $37^{\circ} \mathrm{C}$ with neutrophils in concentrations ranging from 100 to $2500 \mu \mathrm{M}$, significantly inhibited apoptosis of these cells. However, when incubated with a high concentration of aspirin $(10 \mathrm{mM})$, neutrophils were induced towards apoptosis. NCX-4016 had a dual effect on apoptosis of these cells. This nitro-aspirin in concentrations from $1 \mu \mathrm{M}$ to $10 \mu \mathrm{M}$ significantly inhibited apoptosis of rat neutrophil granulocytes after 24 hours of incubation at $37^{\circ} \mathrm{C}$. Namely, the spontaneous apoptosis of neutrophil granulocyte was lowered from $45 \%$ to $30 \%$. However, when NCX4016 was incubated at concentrations of $50 \mu \mathrm{M}$ and higher, neutrophils were induced towards apoptosis. The effect was concentration dependent and $500 \mu \mathrm{M}$ induced apoptosis of $100 \%$ cells.

NO-derivative of aspirin NCX-4016 - or $\mathrm{C}_{16} \mathrm{H}_{13} \mathrm{NO}_{7}$ or 2-(acethyloxi)benzoic acid-3(nitrooximethyl) phenyl esther is a white odourless powder with molecular weight of 331.28 and melting point $59-65^{\circ} \mathrm{C}$ (Di Napoli and Papa, 2003). The release of NO from NCX 4016 probably is time and concentration-dependent, (Grosser N and Schröder H, 2000). NCX-4016, as well as aspirin can couse (in vitro and in vivo) inhibition of COX-1 i COX-2 (Fiorucci, 2003). This nitro-derivative of aspirin has all good properties of aspirin (Bandarage and Janero, 2001). Also, it can inhibit proliferation of tumor cell lines and induce apoptosis of these cells (Williams et al., 2003; Tesei et al., 2003; Kashfi et al., 2002). NCX-4016 inhibits apoptosis of endothelial cells by interaction with the caspase pathway. It also inhibits Caspase-1 (IL-1 $\beta$ converting enzyme) in monocytes (Fiorucci et al., 2000). It is possible that the additive effects of NO-release and COX inhibition improve anti-inflammatory activity and tolerability of NCX4016 (Fiorucci et al., 2002).

Neutrophils are highly specialized white blood cells that participate in the host defense against infection (Simon, 2003). These cells are the first line of defense of the innate immune system. Neutrophils are especially important when fighting microorganisms (bacteria and certain fungi) by phagocytosis and release of toxic mediators. They have a short half-life if they are not recruited to a site of 
inflammation. Inflammatory mediators, cytokines, growth factors and chemical mediators mediate the duration of their life-span (Ward et al., 1999; Simon, 2003). The tight regulation that governs neutrophils behavior is necessary because the content of neutrophil granules can be noxious to the host tissue (Simon, 2003). In the resolution of inflammation, the accumulated neutrophils need to be safely removed. Apoptosis plays an important role in eliminating such neutrophils from inflammed tissues. Most studies have been performed on purified blood neutrophils aiming to understand the molecular events that control apoptosis in these cells (Simon, 2003). Apoptosis is the physiologic cell death. The number of neutrophils is regulated in vivo by their production in the bone marrow and by apoptosis. Apoptosis at the inflammatory site appears to be delayed when survival factors are generated by pro-inflammatory cytokines (Akgul et al., 2001).

Due to the importance of NO in apoptosis of neutrophils we examined its concentration in cell culture. In our experiment, NCX4016 decreased the quantity of $\mathrm{NO}$ in neutrophil culture supernatants when incubated with these cells at concentrations higher than $50 \mu \mathrm{M}$. It is possible that these observations are related to the induction of apoptosis in neutrophils. Nitric oxide (NO) was discovered in 1980 by Furchgott and Zawadzki (Blaise et al., 2005; Moncada et al., 1991). It is a highly reactive, colourless gas with no odour. It is a biochemical messenger both intra- and intercelular, and therefore it possesses many important biochemical and physiological properties. As a signalling molecule, it regulates a broad range of important cellular functions, controls the activation of inflammatory cells and modulates the inflammatory response, and it also influences the process of apoptosis (Napoli and Ignarro, 2000; Bandarage and Janero, 2001; Burgaud, et al., 2002; Hunter, 2002). NO influences the apoptosis of neutrophils (but also other cells), possessing both pro- and anti-apoptotic properties, depending on the concentration and source from which it is derived. There is a multitude of data regarding the proapoptotic effect of $\mathrm{NO}$ on neutrophils and its anti-apoptotic effect on many other cell types. Nitric oxide (NO) is the key mediator in a great number of physiological and pathophysiological processes. It can regulate the rate of apoptosis in many cell types including human inflammatory cells. NO has both pro and antiapoptotic properties depending largely on cell type, concentration and flux of NO. Low concentrations of NO (less than $100 \mu \mathrm{M}$ ) (Bogdan et al., 2000) usually have protective effects on cells, whereas higher concentrations derived from an inducible isoform of NO synthase drive cell death (Taylor et al., 2003). NO is able both to promote and delay inflammatory cell apoptosis and the mechanisms are still not fully elucidated. Also, NO donation can inhibit Nuclear Factor kB (NF-kB), which is a transcription factor involved in inflammation. NF-kB regulates the synthesis of cytokines, cytokine receptors and adhesion molecules (Fiorucci et al., 2004).

Based on the results of our work, the following may be concluded: NCX4016 has a dichotomal effect on apoptosis of rat inflammatory neutrophils in vitro. Namely, in concentrations of 1-10 $\mu \mathrm{M}$, NCX4016 inhibits apoptosis, but in concentrations from $50 \mu \mathrm{M}$ to $500 \mu \mathrm{M}$, it has the opposite effect, i.e. induces apoptosis. The fact that this nitro-aspirin causes inhibition of neutrophil apoptosis in very low concentrations, and that it induces apoptosis in higher concentrations 
is a very important finding that contributes to our knowledge of the pharmacologycal effects of NCX4016.

\author{
Address for correspondence: \\ Prof. Vitomir Ćupić \\ Department of Pharmacology and Toxicology, \\ Faculty of Veterinary Medicine, \\ Belgrade, Serbia \\ E-mail:vcupic@vet.bg.ac.yu
}

\title{
REFERENCES
}

1. Akgul C, Moulding DA, Edwards SWI, 2001, Molecular control of neutrophil apoptosis, FEBS letters, 487, 318-22.

2. Awtry EH, Loscalzo J, 2000, Aspirin. Circulation, 101, 1206-18.

3. Bandarage UK, Janero DR, 2001, Nitric oxide-releasing nonsteroidal anti-inflammatory drugs: novel gastrointestinal-sparing drugs, Mini Rev Med Chem, 1, 1, 57-70.

4. Blaise GA, Gauvin D, Gangal M, Authier S, 2005, Nitric oxide, cell signaling and cell death, Toxicol, $208,2,177-92$.

5. Bogdan C, Röllinghoff M, Diefenbach A, 2000, Reactive oxygen and reactive nitrogen intermediates in innate and specific immunity, Curr Opp Immunol, 12, 64-76.

6. Bolla M, Momi S, Gresele P, Del Soldato P, 2006, Nitric oxide-donating aspirin (NCX 4016): an overview of its pharmacological properties and clinical perspectives, Eur J Clin Pharmacol, 62, Suppl 1, 145-54.

7. Brune B, von Knethen A, Sandau KB, 1999, Nitric oxide (NO): an effector of apoptosis, Cell death and differentiation, 6, 969-75.

8. Burgaud JL, Riffaud JP, Del Soldato $P, 2002$, Nitric-oxide releasing molecules: a new class of drugs with several major indications, Curr Pharm Des, 8, 3, 201-13.

9. Čolic $M, 2004$, Apoptoza neutrofilnih granulocita i njen značaj za regulaciju inflamacije. U: Apoptoza - eksperimentalna i klinička iskustva. Zbornik radova sa naučnog skupa. Urednik: ZL Kovačević. Srpska akademija nauka i umetnosti, Ogranak Novi Sad, 69-80.

10. Ćupić V, 1999, Najčešća trovanja u veterinarskoj medicini, IŠ Stručna knjiga, Beograd,

11. del Soldato P, Sorrentino R, Pinto A, 1999, NO-aspirins: a class of new anti-inflammatory and antithrombotic agents, Trends Pharmacol Sci, 20, 8, 319-23.

12. Di Napoli M, Papa F, 2003, NCX-4016 NicOx, Curr Opin Investig Drugs, 4, 9, 1126-39.

13. Dlamini Z, Mbita Z, Zungu M, 2004, Genealogy, expresion, and molecular mechanisms in apoptosis, Pharmacol Therap, 101, 1-15

14. Elliot SN, McKnight W, Cirino G, Wallace JL, 1995, A nitric oxide-releasing NSAID accelerates gastric ulcer healing in rats, Gastroenterol, 109, 2, 524-30.

15. Fiorucci S, Distrutti E, Mencarelli A, Rizzo G, Lorenzo AR, Baldoni M et al, 2004, Cooperation between aspirin-triggered lipoxin and nitric oxide (NO) mediates antiadhesive properties of 2(acetyloxy)benzoic acid 3-(nitrooxymethyl) phenyl ester (NCX-4016) (NO-aspirin) on neutrophil-endothelial cell adherence, $J$ Pharmacol Exp Ther, 309, 1174-82.

16. Fiorucci S, Mencarelli A, Meneguzzi A, Lechi A, Morelli A, Del Soldato P, Minuz P, 2002, NCX-4016 (NO-aspirin) inhibits lipopolysaccharide-induced tissue factor expression in vivo: role of nitric oxide, Circulation, 106, 3120-25.

17. Fiorucci S, Santucci L, Cirino G, Mencarelli A, Familiari L, Del Soldato $P$ et al, 2000, IL-1 beta converting enzyme is a target for nitric oxide-releasing aspirin: new insights in the antiinflammatory mechanism of nitric oxide-releasing nonsteroidal antiinflammatory drugs, $J$ Immunol, 165, 5245-54.

18. Fiorucci S, Santucci L, Wallace JL, Sardina M, Romano M, del Soldato P et al, 2003, Interaction of a selective cyclooxygenase-2 inhibitor with aspirin and NO-releasing aspirin in the human gastric mucosa, Proc Nat Acad Sci USA, 100, 10937-41. 
Acta Veterinaria (Beograd), Vol. 57. No. 5-6, 403-412, 2007.

19. Girard D, 2003, Activation of human polymorphonuclear neutrophils by environmental contaminants, Rev Environ Health, 18, 2, 77-93.

20. Green LC, Wagner DA, Glogowski J, Skipper PL, Wishnok JS, Tannenbaum SR, 1982, Analysis of nitrate, nitrite and $\left({ }^{15} \mathrm{~N}\right)$ nitrate in biological fluids, Anal biochem, 126, 131-8.

21. Grosser N, Schröder $H, 2000$, A common pathway for nitric oxide release from NO-aspirin and glyceryl trinitrate, Biochem Biophys Res Comm, 274, 255-8.

22. Guimaraes CA, and Linden R, 2004, Programed cell death, Eur J Biochem, 271, 1638-50.

23. Hinz B, Brune K, 2002, Cyclooxigenase-2 - 10 years later, J Pharmacol Exp Therap, 300, 367-75.

24. Hunter R, 2002, Nitric oxide, iNOS and inflammation in veterinary medicine, Anim Health Res Rev, 3 , 2, 119-33

25. Kam PCA, Ferch NI, 2000, Apoptosis: mechanisms and clinical implications, Anaesthesia, 55, 1081-93.

26. Kashfi K, Ryan Y, Qiao LL, Williams JL, Chen J, Del Soldato $P$ et al, 2003, Nitric oxide-donating nonsteroidal anti-inflammatory drugs inhibit the growth of various cultured human cancer cells: evidence of a tissue type-independent effect, J Pharmacol Exp Ther, 303, 3, 1273-82.

27. Maianski NA, Maianski AN, Kuijpers TW, Roos D, 2004, Apoptosis of neutrophils, Acta Haematol, 111, 56-66.

28. Mariotto S, Menegazzi M, Carcereri de Prati A, Cuzzolin L, Adami A, Suzuki HG et al, 1995, Protective effect of NO on gastric lesions and inhibition of expression of gastric iNOS by flurbiprofen and its nitro derivative, nitroflurbiprofen, $\mathrm{Br} J$ Pharmacol, 116, 1713-4.

29. Migita K, Eguchi K, Kawabe Y, Mizokami A, Tsukada T, Nagataki S, 1994, Prevention of anti-CD3 monoclonal antibody-induced thymic apoptosis by protein tyrosine kinase inhibitors, $J$ Immunol, 153, 8, 3457-65.

30. Moncada S, Palmer RMJ, Higgs EA, 1991, Nitric oxide: physiology, patophysiology and pharmacology, Pharmacol Rev, 43, 2, 109-41.

31. Muscara MN, McKnight W, Del Soldato P, Wallace JL,1998, Effect of NO-naproksen on hxpertension amnd gastric damage induced by chronic NO inhibition in the rat, Life Sci, 62, PL 235-PL 240.

32. Napoli C, Ignarro LJ, 2003, Nitric oxide - releasing drugs, Ann Rev Pharmacol Toxicol, 43, 97-123.

33. Simon HU, 2003, Neutrophil apoptosis pathway and their modifications in inflammation, Immunol Rev, 193,101-10

34. Taylor EL, Megson IL, Haslett C, Rossi AG, 2003, Nitric oxide: a key regulator of myeloid inflammatory cell Apoptosis, Cell Death Differ, 10, 418-30.

35. Tesei A, Ricotti L, Ulivi P, Medri L, Amadori D, Zoli W, 2003, NCX-4016, a nitric oxide-releasing aspirin derivative, exhibits a significant antiproliferative effect and alters cell cycle progression in human colon adenocarcinoma cell lines, Int J Oncology, 22, 1297-302.

36. Vane JR, Bakhle YS, Botting RM, 1998, Cyclooxigenases 1 and 2, Ann Rev Pharmacol Toxicol, 38 97-120.

37. Jezdimirović Milanka, Varagić MV, Ćupić V, Jeftić Zorica, 1996, Nesteroidni antiinflamatorni lekovi u veterinarskoj medicini, Veterinarski glasnik, 50, 9-10, 679-87.

38. Vasilev S, Majstorović Ivana, Gašić Sonja, Vučević Dragana, Vasilijić S, Ćupić V et al, 2006, The effects of aspirin on apoptosis of neutrophil granulocytes, Acta Veterinaria, 56, 5-6, 413-21.

39. Wallace JL, Zamuner SR, McKnight W, Dicay M, Mencarelli A, del Soldato P et al, 2004, Aspirin, but not NO-releasing aspirin (NCX-4016), interacts with selective COX-2 inhibitors to aggravate gastric damage and inflammation, Am J Physiol Gastrointest Liver Physiol, 286, 1, G76-81.

40. Ward C, Dransfield I, Chilvers ER, Haslett C, Rossi AG, 1999, Pharmacological manipulation of granulocyte apoptosis: potential therapeutic targets, TIPS, 20, 503-9.

41. Williams JL, Nath N, Chen J, Hundley TR, Gao J, Kopelovich L et al, 2003, Growth inhibition of human colon cancer cells by nitric oxide (NO)-donating aspirin is associated with cycloxygenase-2 induction and beta-catenin/T-cell factor signalling, nuclear factor-kB, and NOsyntase 2 inhibitioon: implication for chemoprevention, Canc Res, 63, 7613-18.

42. Witko-Sarsat V, Rieu P, Descamps-Latscha B, Lesavre P, Halbwachs-Mecarelli L, 2000, Neutrophils: molecules, functions and pathophysiological aspects, Lab Invest, 80, 5, 617. 


\section{EFEKAT NITRO-ASPIRINA NA APOPTOZU NEUTROFILNIH GRANULOCITA}

VASILEV S, VUČEVIĆ DRAGANA, GAŠIĆ SONJA, MAJSTOROVIĆ IVANA, VASILIJIĆ S, ČOLIĆ M i ĆUPIĆ V

\section{SADRŽAJ}

Neutrofilni granulociti imaju najkraći životni vek među leukocitima, koji se može modulisati citokinima i farmakološkim agensima. Efekat nitro-aspirina na apoptozu inflamatornih granulocita do sada nije ispitivan. Zbog toga smo u ovom radu ispitivali efekat nitro-aspirina (NCX-4016) na apoptozu inflamatornih neutrofilnih granulocita pacova. Inflamatorni granulociti su izolovani iz polivinilskih sunđera potkožno implantiranih pacovima Albino Oxford (AO) soja. Inflamatorne ćelije koje su izolovane 20 sati kasnije, najvećim delom (više od $95 \%$ ) su bili neutrofilni granulociti. Ove ćelije su kultivisane 24 sata sa NCX-4016 u koncentracijama od 0,25 $\mu \mathrm{M}$ do $500 \mu \mathrm{M}$. Supernatanti kultura su sakupljani i korišćeni za merenje koncentracije NO. Celije su bojene propidijum jodidom i apoptoza je analizirana na protočnom citofluorimetru, kao i pomoću morfoloških kriterijuma. Ustanovljeno je da u koncentracijama od $1 \mu \mathrm{M}$ do $10 \mu \mathrm{M}$ nitro-aspirin inhibiše, a $\mathrm{u}$ koncentracijama višim od $50 \mu \mathrm{M}$ indukuje apoptozu ovih ćelija, na dozno zavistan način. Nitro-aspirinom indukovana apoptoza je u pozitivnoj korelaciji sa smanjenom produkcijom NO. 